\title{
Immunologic Studies of Prothrombin in Newborns
}

\author{
W. MUNTEAN, W. PETEK, K. ROSANELli, AND I. D. MUTZ \\ Department of Pediatrics, (W. M., I. D. M.), Department of Medical Biochemistry, (W. P.) and Department of \\ Obstetrics and Gynecology (K. R.), University of Graz, Austria
}

\section{Summary}

Prothrombin of newborns was investigated by means of the quantitative immunoelectrophoresis and the two-dimensional immunoelectrophoresis. The plasma of 10 of 24 healthy term newborns and of 5 preterm infants taken immediately after birth showed one prothrombin precipitate in the $\alpha-2-\beta$-globulin position when a buffer containing $25 \mathrm{mM}$ calcium lactate was used. No differences in the mobility and form of the precipitate could be observed as compared to healthy adults. The plasma of the other 14 term newborns and one small-for-date infant showed two precipitates, one in the $\alpha-2-\beta$-globulin position and a second in the $\alpha$-1-globulin position. Twenty-four hr after the injection of vitamin $K$, the precipitate in $\alpha-1$-globulin position was no longer evident. When a buffer without calcium was used in the two-dimensional immunoelectrophoresis, only one precipitate in the $\alpha$-1-globulin position was found in all newborns. In the quantitative immunologic determination, the prothrombin was found to be decreased as compared to that of adults. The quantitative immunologic determination and the activity assay gave equal results in those infants who had only one precipitate in the two dimensional immunoelectrophoresis. In those newborns, who had two precipitates, the quantitative immunologic determination gave higher results than the measurement of the activity assay.

From this study, no evidence of differences between the prothrombin of newborns and that of adults could be derived. Vitamin $K$ deficiency, as judged from the appearance of a second peak in $\alpha$-1-globulin position in the two dimensional immunoelectrophoresis was a frequent finding in term newborns, even on the 1st day of life.

\section{Speculation}

Vitamin $\mathrm{K}$ deficiency is not only an acquired disease in newborns due to an inadequate intake of vitamin $K$ with certain formulas during the 1st days of life, but is also a disease that may exist in term newborns, after a normal pregnancy, before feeding. The significance of an efficient diet of the mother or of vitamin $K$ supplementation to the mother remains to be elucidated.

Many of the coagulation factors, especially the factors of the prothrombin complex, are significantly decreased during the newborn period as compared to adults.

Most studies about blood coagulation in the newborn are dealing with the activity of the coagulation factors. Immunologic determinations of these factors were done in only a few studies $(15,19)$. In this study, prothrombin was investigated with a specific rabbit antiserum. The aim of the study is: 1) to look for possible differences in the immunologic pattern of the prothrombin of newborns and that of adults, and 2) to prove the existence of vitamin $\mathrm{K}$ deficiency in newborns.

\section{MATERIALS AND METHODS}

Thirty newborns were studied. Of them, 24 were term newborns without any perinatal problems, one was a term newborn but small for date. Five were prematures with a gestational age of 31 $35 \mathrm{wk}$. None of these five prematures had perinatal problems, in spite of their prematurity. All but two children received $1 \mathrm{mg} / \mathrm{kg}$ vitamin $\mathrm{K}$ (Konakion) im shortly after birth.

Immediately after birth, blood was drawn from the umbilical vein and again $24 \mathrm{hr}$ afterwards by puncturing a peripheral vein. Blood samples were collected in plastic tubes containing $1 / 10$ volume of $0.1 \mathrm{M}$ trisodium citrate. The plasma was stored at $-20^{\circ}$ $\mathrm{C}$ until the determinations were carried out.

Prothrombin activity was determined by the one stage assay (20) using a test kit of the Behring Co.

Prothrombin was quantified immunologically according to Laurell (11), using a monospecific rabbit antiserum against prothrombin (Behring $\mathrm{Co}$ ): $1 \%$ agarose, barbital buffer of a $\mathrm{pH}$ of $8.6,6-7$ $\mathrm{V} / \mathrm{cm}$.

Calibration curves for the activity and for the quantitative immunologic determination were done with a pooled plasma of 20 healthy adults and the results were expressed in percent of this pooled plasma.

Two-dimensional immunoelectrophoresis $(4,5)$ was done, using rabbit antiserum against human prothrombin 1) with a barbital buffer of a pH of 8.6 and 2) with a barbital buffer of a $\mathrm{pH}$ of 8.6 and $25 \mathrm{mM}$ calcium lactate. Agarose, $1 \%$, first dimension 6-7 V/ $\mathrm{cm}$ for $4 \mathrm{hr}$, second dimension $2-3 \mathrm{~V} / \mathrm{cm}$ for $12-14 \mathrm{hr}$.

Plasma of healthy adults and of adult patients treated with cumarin was run against the samples of the newborns for comparison.

\section{RESULTS}

\section{QUANTITATIVE IMMUNOLOGIC DETERMINATION}

Prothrombin was found significantly decreased to a mean of $34 \%(\mathrm{n}=17, \mathrm{SD} \pm 9)$ immediately after birth and $34 \%(\mathrm{n}=17$, $\mathrm{SD} \pm 8) 24 \mathrm{hr}$ thereafter in newborns as compared to adults (Table 1).

TWO-DIMENSIONAL IMMUNOELECTROPHORESIS WITH A BARBITAL BUFFER WITHOUT CALCIUM

Prothrombin of all of the 30 studied newborns showed one symmetrical peak in the $\alpha$-1-globulin position. The precipitates differed only in height and showed no differences in the form nor in the distance taken from the application points as compared to the plasma of adults (Figs. 1, 2).

TWO-DIMENSIONAL IMMUNOELECTROPHORESIS WITH A BARBITAL BUFFER WITH $25 \mathrm{mM}$ CALCIUM LACTATE

The plasma taken immediately after birth from 10 of the 24 term newborns and of all five preterm infants showed one prothrombin precipitate in the $\alpha-2-\beta$-globulin position. No differences in the pattern of the precipitate could be observed as compared to healthy adults (Figs. 1, 2). The plasma of 14 term newborns and of the small-for-date newborn showed two precipitates, one in the $\alpha-2-\beta$-globulin position and a second in the $\alpha-1$-globulin position (Fig. 1). Eight of them were studied $24 \mathrm{hr}$ after birth. In five of 
Table 1. Results of the two-dimensional immunelectrophoresis, the activity assay and the quantitative immunologic determirfation of prothrombin. Specimens taken at birth and $24 \mathrm{hr}$ thereafter. $\alpha_{1}, \alpha_{2} \beta=$ precipitate in $\alpha-1$-globulin position or $\alpha-2-\beta$-globulin position in the wo-dimensional immunoelectrophoresis with a buffer without calcium lactate and with a buffer containing $25 \mathrm{mM}$ calcium lactate, $++=$ large precipitate, $+=$ small precipitate, $-=$ no precipitate. Results of the activity and the immunologic determination in percent of the mean of a pooled plasma of 20 healthy adults. Vitamin K therapy $=1 \mathrm{mg} / \mathrm{kg}$ Konakion im shortly after birth.

\begin{tabular}{|c|c|c|c|c|c|c|c|c|c|c|c|c|c|c|}
\hline \multirow[b]{3}{*}{ Patients } & \multirow{3}{*}{$\begin{array}{l}\text { Gestational } \\
\text { age (wk) }\end{array}$} & \multicolumn{6}{|c|}{ At birth } & \multirow{3}{*}{$\begin{array}{c}\text { Vitamin } K \\
\text { therapy }\end{array}$} & \multicolumn{6}{|c|}{$24 \mathrm{hr}$ after birth } \\
\hline & & \multicolumn{2}{|c|}{ Without $\mathrm{ca}^{++}$} & \multicolumn{2}{|c|}{ With $\mathrm{ca}^{++}$} & \multirow[b]{2}{*}{ Activity } & \multirow{2}{*}{$\begin{array}{l}\text { Immunologic } \\
\text { determination }\end{array}$} & & \multicolumn{2}{|c|}{ Without $\mathrm{ca}^{++}$} & \multicolumn{2}{|c|}{ With $\mathrm{ca}^{++}$} & \multirow[b]{2}{*}{ Activity } & \multirow{2}{*}{$\begin{array}{l}\text { Immunologic } \\
\text { determination }\end{array}$} \\
\hline & & $\alpha_{1}$ & $\alpha_{2} \beta$ & $\alpha_{1}$ & $\alpha_{2} \beta$ & & & & $\alpha_{1}$ & $\alpha_{2} \beta$ & $\alpha_{1}$ & $\alpha_{2} \beta$ & & \\
\hline 1 & 31 & ++ & - & - & ++ & 27 & 25 & Yes & ++ & - & - & ++ & 25 & 25 \\
\hline 2 & 32 & ++ & - & - & ++ & 25 & 27 & Yes & ++ & - & - & ++ & 23 & 27 \\
\hline 3 & 33 & ++ & - & - & ++ & 23 & 20 & Yes & ++ & - & - & ++ & 30 & 25 \\
\hline 4 & 34 & ++ & - & - & ++ & 30 & 35 & Yes & ++ & - & - & ++ & 30 & 35 \\
\hline 5 & 35 & ++ & - & - & ++ & 23 & 25 & Yes & ++ & - & - & ++ & 30 & 27 \\
\hline 6 & $\begin{array}{l}39, \text { small } \\
\text { for date }\end{array}$ & ++ & - & ++ & ++ & 12 & 45 & Yes & ++ & - & - & ++ & 40 & 45 \\
\hline 7 & term & ++ & - & ++ & ++ & 34 & 56 & Yes & ++ & - & - & ++ & 37 & 39 \\
\hline 8 & term & ++ & - & - & ++ & 29 & 30 & Yes & ++ & - & - & ++ & 29 & 30 \\
\hline 9 & term & ++ & - & + & ++ & 29 & 40 & Yes & ++ & - & - & ++ & 25 & 28 \\
\hline 10 & term & ++ & - & ++ & ++ & 23 & 40 & Yes & ++ & - & - & ++ & 11 & 24 \\
\hline 11 & term & ++ & - & + & ++ & 29 & 36 & Yes & ++ & - & - & ++ & 34 & 29 \\
\hline 12 & term & ++ & - & $+t$ & ++ & 72 & 40 & Yes & ++ & - & + & ++ & 40 & 50 \\
\hline 13 & term & ++ & - & - & ++ & 52 & 36 & Yes & ++ & - & - & ++ & 30 & 36 \\
\hline 14 & term & ++ & - & ++ & ++ & 22 & 40 & & & & & & & \\
\hline 15 & term & ++ & - & - & ++ & 25 & 23 & Yes & ++ & - & - & ++ & 37 & 40 \\
\hline 16 & term & ++ & - & + & ++ & 27 & 31 & No & ++ & - & ++ & ++ & 19 & 40 \\
\hline 17 & term & ++ & - & + & ++ & 32 & 33 & No & ++ & - & + & ++ & 32 & 40 \\
\hline
\end{tabular}

them (cases $6,7,9-11$ in Table 1), the precipitate in the $\alpha$-1globulin position was no longer apparent, in one (case 12), the precipitate in the $\alpha$-1-globulin position had become smaller. In the two children who had not received vitamin $K$, the precipitate in the $\alpha$-1-globulin position persisted or became even stronger (cases 16, 17).

In those adults that were treated with cumarin, two precipitates in $\alpha$-1-globulin and $\alpha$-2- $\beta$-globulin position were found (Fig. 2).

\section{PROTHROMBIN ACTIVITY}

Prothrombin activity correlated well $(P<0.01$ in the paired $t$ test, coefficient of variation 3.5 for the activity assay, 3.1 for the immunologic determination) with the results of the immunologic determination of newborns, who had only one precipitate in the $\alpha-2-\beta$-globulin position in the two-dimensional immunoelectrophoresis with a calcium containing buffer. When two precipitates were found, prothrombin activity was found to be lower than the antigen in all cases but one. When a strong precipitate in the $\alpha-1-$ globulin position was found, this difference was more pronounced (cases 6, 7, 10, 14, 16).

\section{DISCUSSION}

Tests of primary hemostasis taken during the newborn period show a diminished platelet aggregation, in spite of normal adhesion or retention of platelets $(14,17)$. Some coagulation factors, especially those factors of the prothrombin complex, are significantly decreased $(7,9,16)$. In spite of this in vitro impaired platelet function and of the lower activity of coagulation factors, term newborns have no bleeding tendency. On the contrary, the bleeding time is even shorter than in adults (24) and signs of hypercoagulability have been described in newborns $(10,15)$. Until now, this discrepancy between the in vitro and in vivo behavior of the coagulation system has not been entirely explained. An increased risk of bleeding has been reported in preterm infants; this is due mainly to an enhanced vascular fragility and not to a defect in the coagulation system (3).

A speculative explanation for this discrepancy between in vivo and in vitro coagulation is the presumptive existence of function- ally different coagulation factors during the newborn period. Witt et al. (25) has shown impressive evidence of a fetal fibrinogen that persists during the first few days after birth.

The decreased levels of prothrombin in the newborn are usually explained by an impaired synthesis in the liver and by a deficiency of vitamin K. "Haemorrhagic disease of the newborn" describes a bleeding tendency in otherwise inconspicuous newborn infants due to very low activity of the prothrombin complex. It has been shown that this disorder occurs more frequently in breast fed infants who have not received supplemental prophylactic vitamin $\mathrm{K}$ injections (23). Breast milk has only one quarter of the vitamin $K$ contained in cow's milk formulas. Although several authors have demonstrated that the administration of vitamin $K$ to the newborn is to some extent beneficial in raising the activity of the factors of the prothrombin complex $(1,2,23)$, the significance of vitamin $K$ deficiency during the newborn period has been questioned by others $(4,10,18)$. This discrepancy might be explained by the wide range in variability of the prothrombin activity in normal neonates (2) and by changes in hematocrit and blood volume during the first days of life. These facts make it difficult to estimate the effect of vitamin $\mathrm{K}$ administration when measuring the activity of the coagulation factors alone.

Vitamin $\mathrm{K}$ is essential for the production of the factors of the prothrombin complex. When there is a deficiency in vitamin $\mathrm{K}$, an inactive prothrombin molecule is synthesized by the liver which differs from the normal prothrombin only in two characteristics: it can not be activated into thrombin by physiologic activators (8) and it fails to bind calcium. Two types of calcium binding sites have been described in human prothrombin, the strong calcium binding sites being clearly vitamin $\mathrm{K}$ dependent. These sites, whose molecular nature has been elucidated in bovine prothrombin, are responsible for the phospholipid binding. They consist of carboxyglutamic acid residues. Their carboxylation has been shown to be directly vitamin $\mathrm{K}$ dependent $(13,22)$.

The inactive prothrombin of vitamin $\mathrm{K}$ deficiency reacts with the antibody in the same way as the normal prothrombin $(5,6)$. Therefore, in the quantitative immunoelectrophoresis, the normal and the inactive prothrombin are measured. This explains why in vitamin $\mathrm{K}$ deficiency the immunologic determination gives higher results than the measurement of the activity of prothrombin; in 

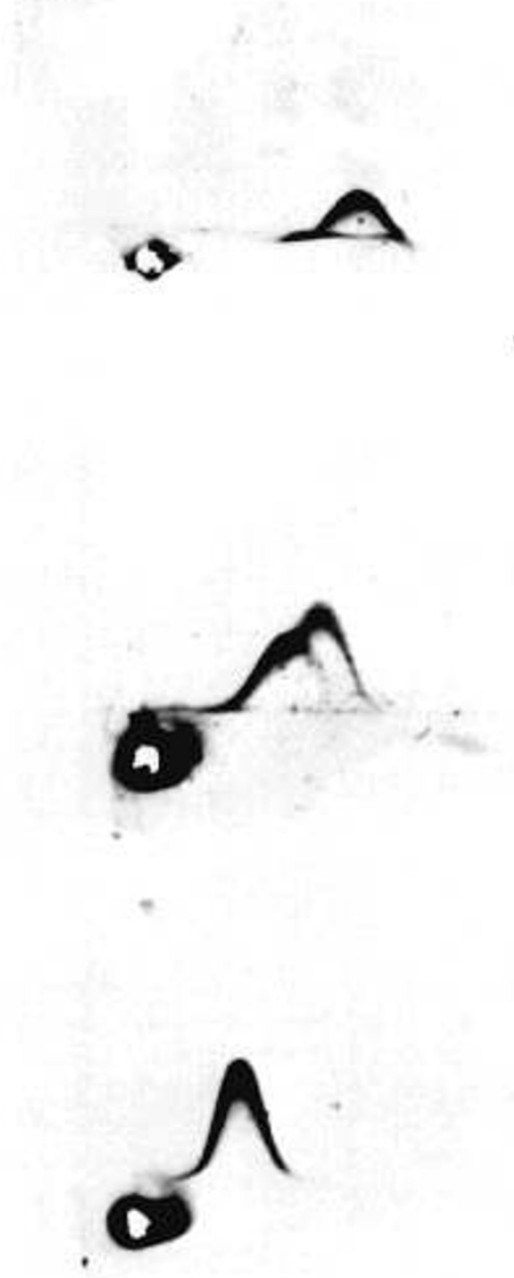

$-$

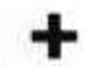

Fig. 1. Two-dimensional immunoelectrophoresis of prothrombin of a small-for-date infant, gestational age of $39 \mathrm{wk}$ (case 6 in Table 1). 1\% agarose, barbital buffer, $\mathrm{pH} 8.6$, first dimension $6-7 \mathrm{~V} / \mathrm{cm}$, for $4 \mathrm{hr}$, second dimension $2-3 \mathrm{~V} / \mathrm{cm}$ for $12-14 \mathrm{hr}$. Top: specimen taken immediately after birth. With a buffer without calcium lactate, only one precipitate in $\alpha$-1globulin position is found. Middle: the same specimen as above, but the buffer containing $25 \mathrm{mM}$ calcium lactate. A second precipitate in $\alpha-2-\beta$ globulin position is found. Bottom: specimen taken $24 \mathrm{hr}$ after the administration of vitamin $\mathrm{K}$ im to the newborn. Only one precipitate in $\alpha-2-\beta$ globulin position can be demonstrated with a buffer containing $25 \mathrm{mM}$ calcium lactate.

healthy probands, results of these two methods strictly correlate.

Due to the fact that the inactive prothrombin does not bind calcium, it migrates to the $\alpha$-1-globulin position; on the other hand, the intact prothrombin migrates to the $\alpha-2-\beta$-globulin position when a calcium containing buffer is used for the electrophoresis. When the buffer does not contain calcium, these differences can not be observed: both normal and inactive prothrombin are found as one homogeneous precipitate to be in the $\alpha$-1-globulin position $(5,6,21)$.

In this study, no differences between the prothrombin of newborns and that of adults were found: in the two-dimensional immunoelectrophoresis, the prothrombin of newborns showed exactly the same mobility and pattern of the precipitate as the prothrombin of adults. The results of the activity assay and the quantitative immunologic determination correlated strictly in in-
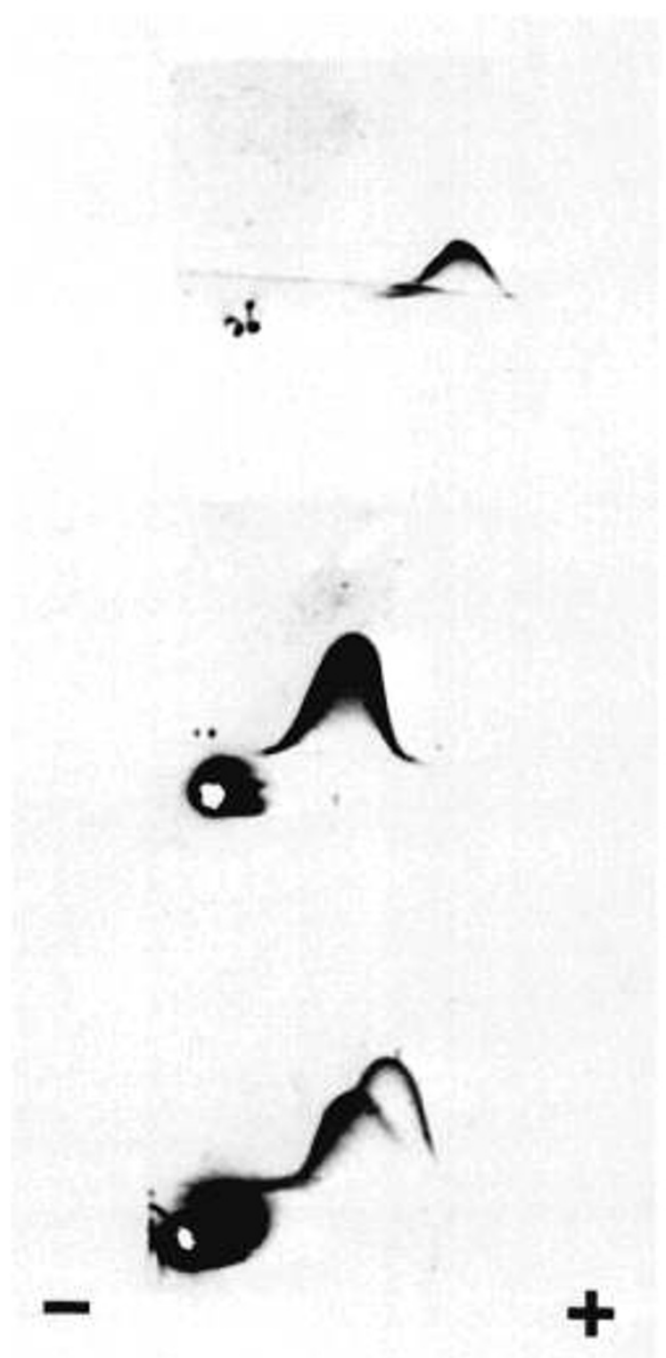

Fig. 2. Two-dimensional immunoelectrophoresis of prothrombin. Top: plasma of a healthy adult, the buffer without calcium lactate. One precipitate in $\alpha$-1-globulin position is found. Middle: the same plasma, the buffer containing $25 \mathrm{mM}$ calcium lactate. One precipitate in $\alpha-2-\beta$-globulin position is found. Bottom: plasma of a patient treated with cumarin, the buffer containing $25 \mathrm{mM}$ calcium lactate. Two precipitates, one in $\alpha$-1globulin and another in $\alpha-2-\beta$-globulin position are found.

fants who did not show any signs of vitamin $\mathrm{K}$ deficiency in the two-dimensional immunoelectrophoresis with one exception-in case 12 , the high value of the prothrombin activity is most likely due to an activation of the specimen before testing. It is, therefore, unlikely that a prothrombin variant, which is less active in the one stage assay, is synthesized during the newborn period.

In this study, vitamin $\mathrm{K}$ deficiency in healthy term newborns was a frequent finding, as judged from the appearance of a second peak in the $\alpha$-1-globulin position in the two-dimensional immunoelectrophoresis and from the difference between activity and antigen levels. After administering vitamin $\mathrm{K}$, these laboratory findings of vitamin $\mathrm{K}$ deficiency were no longer evident.

Interestingly, the findings of vitamin $\mathrm{K}$ deficiency were present in the term newborns even immediately after birth. It is well known that the highest incidence of $\mathrm{Mb}$. hemorrhagicus neonatorum occurs during the 3rd-5th day of life. Because most healthy term newborns will be breast fed, the recommendation to administer prophylactic vitamin $\mathrm{K}$ injections not only to preterm infants or those of high risk, but also to all newborns, seems to be justified.

\section{REFERENCES AND NOTES}

1. Aballi, A. J.: The action of vitamin $\mathrm{K}$ in the neonatal period. Southern Med. J., 58: 48 (1965). 
2. Aballi, A. J., Lopez Banus, U., and De Lamerens, S.: Coagulation studies in the newborn period. I. Alterations of thromboplastin generation and effects of vitamin $\mathrm{K}$ on full-term and premature infants. Am. J. Dis. Child., 94: 594 (1957).

3. Bleyer, W. A., Kakami, N., and Shepard, T. H.: The development of hemostasis in the human fetus and newborn infant. J. Pediatr.. 79: 838 (1971)

4. van Doorm, J. M., Muller, A. D.. and Hemker, H. L.: Heparin-like inhibitor, not vitamin-K deficiency, in the newborn. Lancet, 1: 852 (1977).

5. Gangrot, P. O., and Niléhn, J. E.: Immunochemical determination of human prothrombin. Scand. J. Clin. Lab. Invest., 21: 238 (1968).

6. Gangrot, P., O., and Niléhn, J. E.: Plasma prothrombin during treatment with dicumarol. II. Demonstration of an abnormal prothrombin fraction. Scand. J. Clin. Lab. Invest., 22: 23, (1968).

7. Göbel, U., Petrich, C., and Schmidt, E.: Prothrombin, akzelerin und konvertin bei gesunden und kranken Neugeborenen. Helv. Paediatr. Acta, 28: 291 (1973).

8. Hemker, H. C., Bas, B. M., Muller, A. D.: The reaction between prothrombin and staphylocoagulase. Biochem. Biophys. Acta, 379: 180 (1975).

9. Hurlet-Birk Jensen, A., Josso, F., Zamet, P.. Monset-Couchard, M., and Min kowsky. A.: Evolution of blood clotting factor levels in premature infants during the first 20 days of life. A study of 96 cases with comparison between clinical status and blood clotting levels. Pediatr. Res., 7: 638 (1973).

10. Künzer, W.: Die blutgerinnung bei neugeborenen und ihre störungen. Klin Wschr., 49: 1 (1971).

11. Laurell, C. B.: Antigen-antibody crossed electrophoresis. Anal. Biochem., 10:358 (1965)

12. Laurell, C. B.: Quantitative estimation of proteins by electrophoresis in agarose containing antibodies. Anal. Biochem., 15: 45 (1966).

13. Magnusson, S., Sottrup-Jensen, L., Petersen, T. E., Morris, H. R.. and Dell, A. Primary structure of the vitamin $\mathrm{K}$ dependent part of prothrombin. FEBS Lett. 44: 189 (1974).

14. Mull, M. M., and Hathaway, W. E.: Altered platelet function in newborns.
Pediatr. Res., 4: 229 (1970).

15. Muntean. W.. Belohradsky, B. H., Klose, H. J., and Riegel, K.: Faktor VIII aktivität und faktor VIII assoziiertes antigen bei neugeborenen. Klin. Päd. 189: 412 (1977).

16. Muntean, W., Müller, W. D.: Gerinnungsuntersuchungen aus kapillarblut bei neugeborenen. Helv. Paediatr. Acta. 3I: 149 (1976)

17. Pandolfi, M., Astedt, B., Cronberg, L., and Nilsson. I. M.: Failure of fetal platelets to aggregate in response to adrenaline and collagen. Proc. Soc. Exp. Biol. Med. 141: 1081 (1972).

18. Sandford. H. N., Shnigensky, I., and Chapin, J. M.: Is administration of vitamin $\mathrm{K}$ to the newborn of clinical value? JAMA, $118: 697$ (1942).

19. Schettini. F., de Mattia, D., and Mautone. A.: Preprothrombin and prothrombin in full-term newborns. Haemostasis, 1: 271 (1972/73)

20. Schröer, H.: Assay for prothrombin. In: N. Bang, F. K. Beller, E. Deutsch, E. F. Mammen: Thrombosis and Bleeding Disorders. p. 175 (Georg Thieme Verlag. Stuttgart, 197!).

21. Schwick, H. G., Trobisch, H., and Heimburger, N.: Leistungsfähigkeit und grenzen immunologischer methoden in der gerinnungsdiagnostik. Internist. 14 160 (1973).

22. Stenflo. J.. Fernlund, P., Egan, W.. and Roepsdorf, P.: Vitamin K dependent modifications of glutamic acid residues in prothrombin. Proc. Nat. Acad. Sci.,
71 : 2730 (1974).

23. Sutherland, J. M.. Glueck, H. I., and Gleser, G.: Hemorrhagic disease of newborn. Breast feedings as a necessary factor in the pathogenesis. Amer. J. Dis. Child., 113: 524 (1967).

24. Sutor, A. H., Heidmann, M., and Künzer, W.: Die blutungszeitbestimmung im kindesalter und ihre klinische anwendung. Med. Welt. 25: 401 (1974).

25. Witt, I., Hasler, K., and Karitzky, D.: Nachweis von fetalem fibrinogen im neugeborenen-plasma. Klin. Wschr.. 51: 703 (1973).

26. Received for publication November 4.1978

27. Accepted for publication June 19, 1979 